\title{
أثر برنامج قائم على الأنشطة التربوية لتنمية بعض مفاهيم الحس الوطني لاى طقل الروضة بمدينة جازان
}

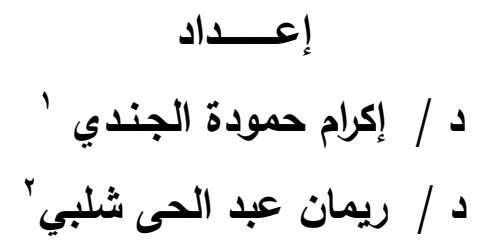

ملخص البحث

يهدف البحث الحالي إلى تتمية قدرة الطفل على معرفة مفاهيم الحس الوطني وتمكينه من ممارستها كسلوك وممارسة من خلال تتمية قيم الانتماء وتقدير قيمة العمل في المجتمع وبصفة خاصة مهنة الثرطي ومهامه المختلفة داخل المجتمع والتأكيد على اكسابه القدرة على التمييز بين الملكية العامة والخاصة ـ وتم تطبيق البحث على عينة عشوائية مكونة من (10) طفلا بالمستوى الثالث تتزاوح أعمارهم بين ( 0-7) سنوات - بروضة الحسيني التابعة للإدارة التعليمية بمدينة جازان. باستخدام مقياس مصور لمفاهيم الحس الوطني • وتم معالجة البيانات باستخدام الاختبار الإحصائي ويلكوكسون بالإضافة الى استخدام اسلوب التحليل الوصفي لتفسير النتائج • وأسفرت نتائج البحث على وجود فروق دالة احصائيا عند مستوى دلالة (0...بين درجات الأطفال في التطبيق القبلي والبعدي لصالح التطبيق البعدي مما يدل على أثز الأنشطة في اكساب الطفل بعض مفاهيم الحس الوطنى ـ كما توصل البحث الى أن الطفل تتمو لديه القدرة في المعارف والمفاهيم المرتبطة بمفاهيم الحس الوطنى إذا ما ألقى عليها الضوء وتفعيل الأنشطة التربوية والممارسات المرتبطة بها. وأوصى البحث بضرورة نطوير المناهج المقدمة لطفل الروضة بما يتوافق مع المتغيرات المجتمعية التي تحيط به وتتيكل فكره وشخصيته ـ وتنبى مشروع قومي على مستوى المملكة لصياغة المعايير القومية المرتبطة بمرحلة رياض الأطفال في ضوء التغيرات العالمية .

الكلمات المفتاحية : الأنثطة التريوية - مفاهيم الحس الوطنى - طقل الروضة. مدرس بقسم رياض الأطفال - كلية التربية جامعة طنطا

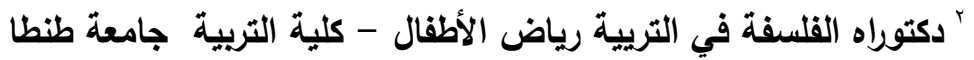




\section{$\underline{\text { Abstract }}$ \\ The effect of a program based on educational activities to develop some concepts of national sense among the kindergarten child in Jizan.}

\section{Dr. Ikram Hamouda El-Gendy Dr. Riemann Abdel Hai Shalaby}

The current research aims to develop the child's ability to know the concepts of the national sense and enable him to practice it as behavior and practice through developing the values of belonging and assessing the value of work in society and in particular the policeman's profession and its various tasks within society and emphasizing its acquisition of the ability to distinguish between public and private ownership. The research was applied to a random sample consisting of (15) children at the third level between the ages of (5-6) years - Al-Husseini Kindergarten of the Educational Administration in the city of Jazan. Using an illustrated scale of national sense concepts. The data was processed using the Wilcoxon statistical test in addition to using the descriptive analysis method to interpret the results. The results of the research resulted in the presence of statistically significant differences at the level of significance (05.) between the degrees of children in the pre and post application in favor of the post application, which indicates the effect of the activities on giving the child some concepts of national sense. The research also concluded that the child grows with the ability in knowledge and concepts Associated with the concepts of national sense if it is highlighted and activated educational activities and related practices. The research recommended the necessity of developing the curricula offered to the kindergarten child in a way that is compatible with the societal changes that surround him and shape his idea and personality. And he adopted a national project in the Kingdom to formulate national standards related to the kindergarten stage in light of global changes.

\section{Key Words: Educational activities - concepts of national sense - kindergarten child.}




\section{مقدمـــة البحث:}

تُشكل التربية من أجل تنمية مفاهيم الحس الوطنى حجر الأساس في التربية على المشاركة والموائمة في مجتمع واحد أكثر تكيفاً قادراً على مواجهة التحديات والمخاطر معاً ، وإنَّ العمل للوصول إلى مجتمع المواطنة يُشكل هماً أساسياً على عاتق المنظومة السياسية والتريوية ، لبناء مواطن قادر على تحقيق سبل التنمية لمجتمعيه في ظل التغيرات الذي يشهها العالم اليوم، حيث أصبحت من القضايا التي تفرض نفسها علينا بقوة عند السعي لمعالجة أبعاد الإصلاح والتطوير الثامل للمجتمعات.

فتعتمد المواطنة على قيم ومبادئ الإنسان السوي تجاه وطنه ومجتمعه، وممارستها يوميا بشكل عادى في حياته ونابعه من أعماق ضميره، بل تعد جزعاً راسخا فى شخصيته وتكوينه. لذا تسعى المملكة العربية السعودية لترسيخ أهم أهداف التربية في تنشئة المواطن الصالح المخلص في خدمة وطنه وأمته الاسلامية التي ينتمى اليها ـ (وزارة المعارف ، 999 ( 9 ، صد ب ) ) . فالتربية تشكل عقول الأجيال وتثرى لايهم قيم العمل والخير والسلوك الاجتماعي ، كالعدل واللديمقراطية والحرية وجميع القيم الفاضلة التي تحول الكائن البشري الى كائن اجتماعي ومن ثم

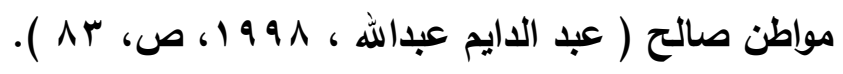

وتعد مرحلة الطفولة المبكرة من أهم المراحل الأنسب لغرس المفاهيم والمعارف والقيم النمائية ، وخاصة المتعلقة بالانتماء والمواطنة، وذلك لأن ترسيخها في مرحلة الطفولة، وتتشئة الطقل عليها تجعلها عنصراً مكوناً في بناء شخصيته متميزة . فالقيم التي تتم تنشئة الاطفال عليها في سن مبكرة تكون اكثر ثباتاً ، وتثكل معيار سلوك الفرد القويم في مستقبل حياته ـ كغرس قيم احترام الممتلكات العامة ، و الحفاظ على الحدائق العامة بالمرتبة ذاتها التي نهتم ونعتتي بحديقة المنزل، بالإضافة إلى الاهتمام بنظافة الثارع وكانه فناء للمنزل ، وإلنظر الى اثاث المدرسة بمرتبة الاثاث المنزلي الذى يحيا عليه ، وكل هذه القيم التي قـ تبدو رمزية ،الا انها في الحقيقة تعزز بشكل عملي احترام الفرد للممتلكات العامة ،والمواطنة الصالحة ، والقيم الجمالية ، والحضارية ، وتثكل قاعدة قوية للتعليم المدرسي اللاحق في هذا المجال. كما انها تغرس مفاهيم الامانة والاخلاص للوطن والاعتزاز به بحيث لا يفكر الفرد بالعبث

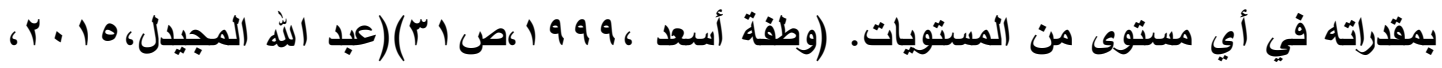
ص^^ץ) فالطفولة المبكرة مرحلة مؤهله لنشيء جيل مدرك وواع بالمفاهيم التي تحملها المواطنة، ورسوخها منذ نعومة أظافره بتحويل ردود فعله من مجرد ملقن أو مستقبل لمفاهيم الحس الوطنى ، 
أو ترديد الشعارات الى مواطن يحيا بها معبر بذلك في قيمه و سلوكياته ومعتقداته وأفكاره واتجاهاته ـ كأن يعمل على حماية وطنه والدفاع عنه ـ فالمواطنة بهذه الصورة لن تظهر على هذا النحو إلا عندما تتوفر مقوماتها الفعالة والمؤئرة في حياة الافراد ، المتمثلة في تمتع جميع أفرادها بحقوقهم مقابل أداء ما عليهم من واجبات ، ويالتالي سيكون لدى المواطن شعوراً داخلياً بشرف الانتماء للوطن والفخر به بل ينظر إلى وطنه على أنَّه بيته الكبير الأي يجب الحفاظ عليه وحمايته من جميع الأخطار، والحرص على تحقيق المصلحة العامة قبل مصلحته الشخصية ، والتصدي لكل ما يُخل باستقرار وأمن الوطن والمجتمع حاضراً ومستقبلاً .(الحامد محمد بن محجب ، ؛ . . r ،ص

\section{مبررات البحث:}

وإنطلاقاً مما سبق تحددت مبررات البحث الحالي في النقاط التالية : = عدم قدرة البـرامج وإلمنـاهج التعليميـة الموجـه لريـاض الأطفـال لإثـباع مفـاهيم الحس الـوطنى كممارسة وسلوك وليس كمفهوم نظري لاى الأطفال حيث تحتاج لإلقاء الضوء على بعض المفاهيم والقيم ذات التأثير البالغ • والتي يجب ترسيخها في نفوس الأطفال منذ الصغر مثل : اتباع اللوائح والقوانين ، النظام ، المرور ، النظافة .... ، وتقدير المهن وأدوارها بالمجتمع ( كاببراز دور الشرطي

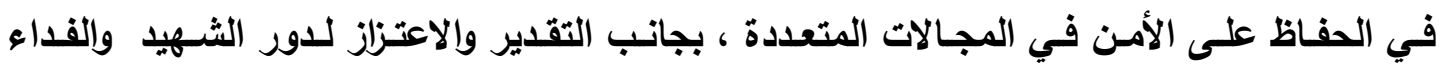
والتضحية من أجل حماية الوطن) . = لـم تحظى مدينـة جـازان بالقدر الكافي مـن الأبحاث التي اهتمـت بمجـال ريـاض الأطفـال وخاصـة مفاهيم الحس الوطني لطفل الروضـة ـ بـالرغم من أنتا في حاجـة إلى تنشئة مواطن مشـارك فعال لمستقبل أفضل بهذه المنطقة الحرجة وما تعانيه من ضغوط مؤثرة .

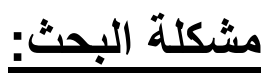

نظرا لكون مدينة جازلان تقع على الثريط الجنويى الحدودي للمملكة والتي تمثل أحد أدرعة الأمن

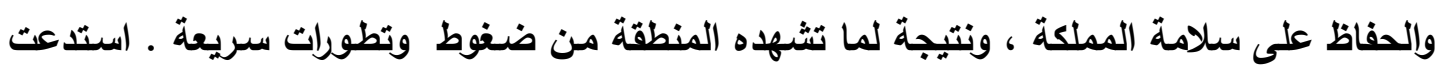
الحاجة الى تنشئة أطفالنـا على القيم التي تربطهم بوطنهم منذ سن مبكره أمراً حتمياً . ومـن هنا تنامى الاحساس بالمشكلة الحالية للبحث التي يمكن صياغتها في التساؤل الرئيسي التالي : :ما أثر برنامج قائم على الأنشطة التريوية لتنمية بعض مفاهيم الحس الوطنى لاى طقل الروضة

بمنطقة جازان؛ ويتفرع من التساؤل الرئيسي التساؤلات الآتية :- 
ا - ما الأنشطة التريويـة المقترحة لتنمية بعض مفـاهيم الحس الوطنى لـى طفل الروضـة بمنطقة

جانان ؟

r - ما أثر الأنشطة المقترحة في تتمية حب الطقل وإنتماءه لوطنه ورموزه ؟

r - ما أثر الأنشطة المقترحة في تتمية تقدير الطقل أهمية المهن وأدوارها بالمجتمع ؟

ـ- ما أثر الأنثطة المقترحة في تنمية قرة الطقل على التمييز بين الملكية العامة والخاصة ؟

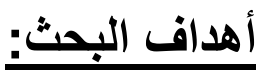

1. التعرف على مدى أهمية ريط خبرات الأطفال المتعلمة بمجتمعهم .

r - إعداد دليل أنشطة تريوية متكاملة لبعض مفاهيم الحس الوطنى المناسبة للطفل وتوظيفها في

حياته اليومية . أعية

ب- تحديد أثر الأنشطة التريوية في تنمية بعض مفاهيم الحس الوطنى للى طفل الروضـة بمنطقة

· جازان

$$
\text { - أهمية البحث: }
$$

- اكتسب البحث الحالي أهميته من أهمية بنـاء الإنسـان المواطن الذي تقع عليه أعباء النهوض الحضاري ويناء الأوطان بشكل عام ولمرحلة الطقولة المبكرة بثكل خاص، وتربية على الموروث المشترك من المبادئ والقيم والعادات والسلوكيات التي تسهم في تشكيل شخصيته كمواطن منتج

وفعال .

- تركز الدراسة الحالية علي التعرف عل الأنشطة التريوية المقترحة الداعمة لتنمية بعض مفاهيم الحس الوطنى لاى طقل الروضة

- تركز الدراســة الحاليـة علـي ترسـيخ قيم ومفـاهيم المواطنـة كتنميـة وعى الطفل لبعض المهـن

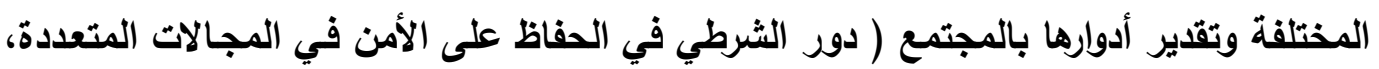

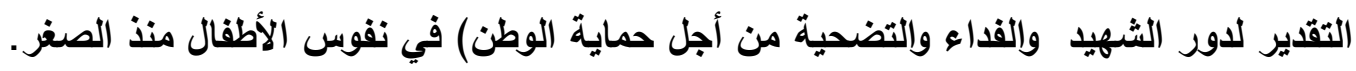
- المحور العملي : من المتوقع أن يفيد البحث الفئات التالية : 1 - يحتل البحث الحالي أهمية كبيرة في غرس قيم الانتماء والمواطنة في نفوس الأطفال بالمجتمع وخاصة مدينة جازان وخاصة قيم الوطن والدفاع عنه والعمل على حماية اراضيها من الأعداء والتضحية من أجله. 
ץ - تأتى أهمية هذا البحث في كونها محاولة للإسـهام في دعم التريويون والعاملون علي العملية

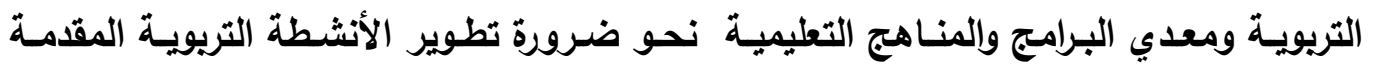
للطقل. ب- قد تفيد معلمـات رياض الأطفال وذلك بتقديم دليل معلم يشتمل على معرفة متكاملة عن قيم ومفاهيم المواطنة ، وكيفية تقديمها للأطفال باستخدام برنامج من الأنشطة التربوية المتكاملة. ع - الطفل نفسه حيث تزود هذه الدراسة الطفل ببعض المعارف والخبرات المرتبطة بمفاهيم الحس هن الوطنى وتأثيرها على ذاته حتى تصبح جزيعاً من شخصيته. فروض البحث: ا - يستطيع طقل الروضة ممارسة مفاهيم الحس الوطنى ( الانتماء لوطن -التمييز بين الممتلكات العامة والخاصة - تقدير قيمة العمل ). ץ- توجد فروق دالـة احصائيا بين التطبيقين القبلي و البعدي على أبعاد مقياس مفاهيم الحس

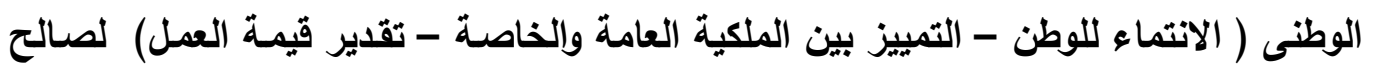

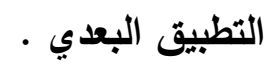
مصطاحاث البحث: البعا: (Program ) : برنامج - مجموعة اجراءات ،و خطوات ،و تعليمات وقواعد يتم اتباعها لنقل خبرات محددة مقروءة ،او مسـموعة أو مرئيـة، مباشـرة، أو غيـر مباشـرة ،تعليميـة او ترفيهيـة او تثقيفيـة ،وذلكـ لفـرد او

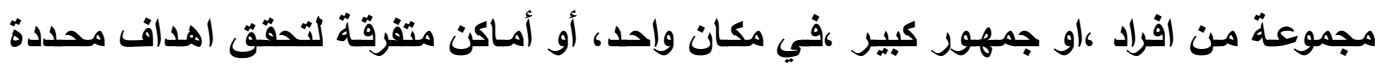

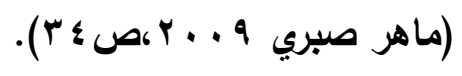

(Educational activities ): - الأنشطة التريوية - يقصد بها : ( مجموعة من الخبرات والممارسـات التي يمارسـها المتعلم ويكتسبها وهي عمليه

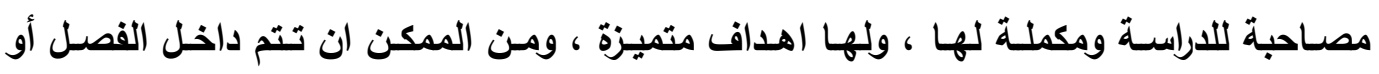

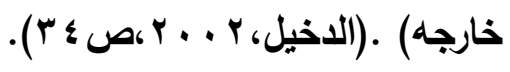

(concepts of national sense): مفاهيم الحس الوطني اتجـاه إيجـابي مـدعم بالحب ، يستشـعر بـه الفرد مـدى انتسـابه نـو هذا الوطن باعتباره عضـوا

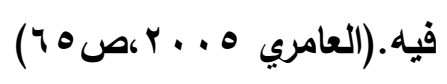

- ميعرفها البحث اجرائيا : بأنها " مجموعة المفاهيم التي يكتسبها الطقل ويمارسها بشكل 
طبيعي تجعله يتجه بمشاعر ايجابية نحو وطنه ـ ويقدر قيمة العمل و دور مهنة الضابط سواء

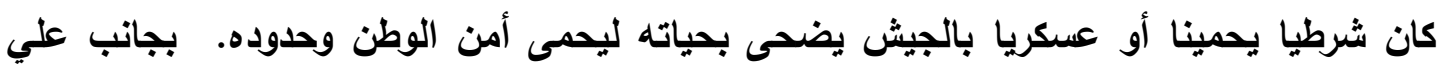
التمييز بين الممتكات العامة والخاصة والمحافظة عليها . (Child kindergarten): - هو طقل مرحلة الطفولة المبكرة الملتحق برياض الأطفال وهي التي تقع بين سن (ع-7 ) سنوات من العمر وهي المرحلة التي يتعلم فيها الطقل أسس السلوك الاجتماعي الذي يعد للعياة

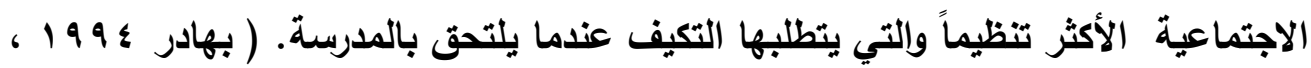

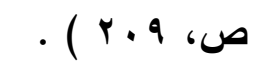
منهج البحث: البحث:

• يستخدم البحث الحالي المنهج التجريبي ( التصميم التجريبي ذو العينة الواحدة).

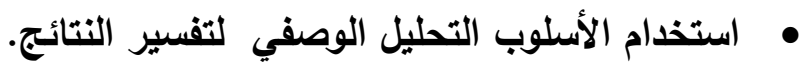
أدوات البحث: 1 - إعداد مقياس مفاهيم الحس الوطنى لاى طفل الروضة. فى ضوء أدبيات الدراسة والدراسات

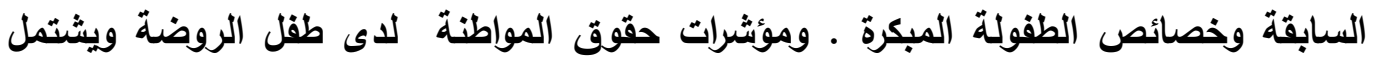

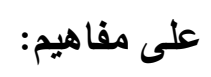
الانتماء للوطن ورموزه .

• تقدير قيمة العمل ( تقدير أهمية مهنة الثرطي وأدواره المختلفة بالمجتمع ). التمييز بين الملكية العامة والخاصة ( اعداد الباحثتان)

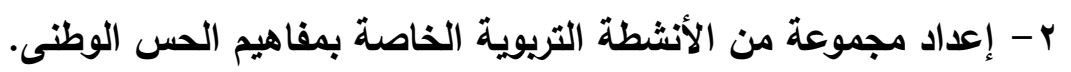
عينة البحث: أعرع:

تم اختيار عينة البحث بطريقة عشوائية لأحد قاعات الروضة وتم التطبيق على أطفال المستوى الثالث بروضـة الحسيني التابعـة لمديريـة صبيا التطليميـة بمدينـة جـانان - المملكـة العربيـة السعودية (حيث أنها روضة نموذجيه ويها عدد مقبول من الأطفال في السن موضوع الدراسة)

$$
\text { حدود البحث: }
$$

اقتصر البحث الحالي على الحدود التالية: 
= الحدود الموضوعية: سعى البحث الحالي لتنمية مفاهيم الحس الوطنى للدى طقل الروضـة من خلال مجموعة من الأنشطة التريويـة المتكاملـة المؤثرة في اكسـاب الطفل مفاهيم الحس الوطنى ( انتماء الطقل لوطنه ورموزه - تقدير الطقل أهمية المهن وأدوارها بالمجتمع - التمييز بين الملكية (العامة والخاصة ). = الحدود البشرية : تم تطبيق البحث على أطفال المستوى الثالث بالروضـة وتتراوح أعمارهم من (7-0) = الحدود المكانية : تم تطبيق البحث بروضة ( الحسيني ) مدينة جازان - المملكة العربية السعودية = الحدود الزمانية : تم تطبيق أنشطة البحث الحالي في الفصل الاول للعام الاراسي (•r. • • م) تطبيق البحث: في ضوء مشكلة البحث وفروضه تم تطبيق البحث على النحو التالي : - الاطلاع على المراجع المتخصصة والدراسات والبحوث السابقة المتعلقة بموضوع البحث

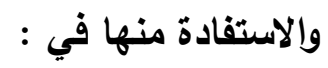
1. إعداد الإطار النظري وتحديد مشكلة البحث وفروض البحث وإعداد الأدوات . r. تحديد مفاهيم الحس الوطنى التي يمكن تبسيطها و تقديمها في البحث و التي تتاسب طفل

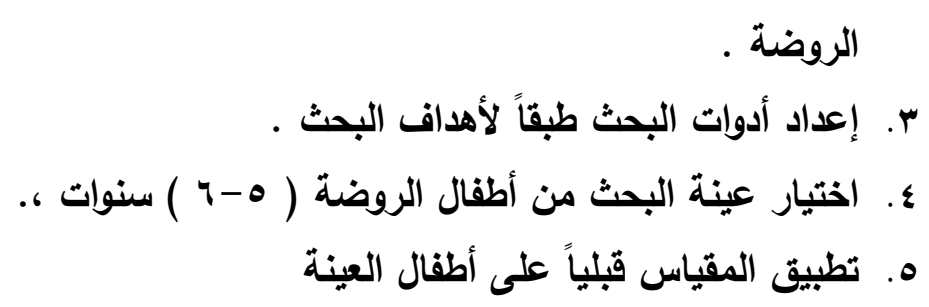
7. V . تطبيق المقياس بعدياً على أطفال العينة A. جمع النتائج وإجراء المعالجات الإحصائية.

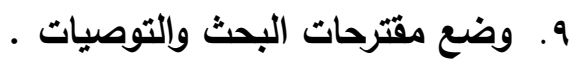
الإطار النظري للبحث:

المحور الأول: أهمية التربية من أجل المواطنة لطقل الروضة . تربية الحس الوطنى: إن مجتمعنا اليوم يواجه كثير من التحديات الداخلية والخارجية التي تهدد أمنه واستقراره ويعد أخطر هذه التحديات ما يشكل تأثيرًا سلبيًا على مقومات المواطنة والانتماء عند الأفراد وفى أفكارهم وثقافاتهم وقيمهم · والحس الوطنى ليس ترديدًا للشعارات بل هو واجباً وممارسة وسلوك ينم عن 
إيمان الفرد بأهمية دوره كمواطن مؤديًا لواجباته و متمسكًا بحقوقه و محترماً حقوق غيره ، وحريص على مصلحة مجتمعه العامة بنفس حرصه على حقوقه ، ومؤديًا لواجباته بكل أمانة و إتقان.ويؤكد (أسامة خلاف) أن بعض الباحثين المهتمين بتربية الطقل رصدوا تهايدا كبيرًا يمثل خطورة على الأطفال، اتضح في المشكلات السلوكية الغير مقبولة التي يمارسونها في حياتهر ، مما يلل على ضعف انتمائهم وولائهم ووجود قصور في الوعي بواجبات وحقوق الوطن .لذا أوصى ضرورة إعادة النظر في البرامج المقدمة للطقل في ضوء التحديات العالمية التي يوجهها مجتمعنا في كافة المجالات الحياتية الأمر الذى يتطلب دعم الاطفال بالقدر الكافي بما يؤهلهم للتكيف مع

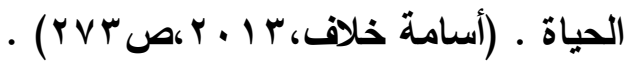
فالحس الوطني السليم هو الأى يجعل الفرد يدرك أنه جزعًا من مجتمعه وأمته ـ ولقد ركزت سياسة التعليم بالمملكة العربية السعودية على تربية المواطن المؤمن المنتمي لبلاه وأمته ليكون لبنه صالحة في بناء الأمة ، بالإضافة الى تنمية إحساس الافراد بتحديات المجتمع في المجالات الثقافية والاقتصادية والاجتماعية ليكونوا قادرين على العطاء والتضحية والمساهمة في التظلب على هذه التحديات ـ وتعتبر الوطنية أكثر عمقاً من المواطنة إذا تمثل أعلى درجات المواطنة ـ ويكتسب الفرد المواطنة بمجرد انتسابه الى جماعة أو دولة ـ بينما لا يكتسب صفة الوطنية إلا بعمل الفعل الإيجابي لصالح الجماعة .(فه ابراهيم ، ه . . ب) .

أهية تنمية الحس الوطنى لطقل الروضة : بتناول أراء بعض الباحثين المهتمين بمجالي القيم و المواطنة للطقل : فتؤكد دراسة (هناء حمود) على أهمية غرس القيم والمفاهيم والمعارف في نفوس الأطفال وتنشئته عليها منذ السن المبكر • وتثير الى أن مرحلة الروضة تلعب تريوياً حيوياً في تثكيل السلوك القيمي المرغوب اجتماعياً للطفل . وركزت الدراسة على تنشئة الطقل عليها وجعلها عنصراً مكوناً في بناء

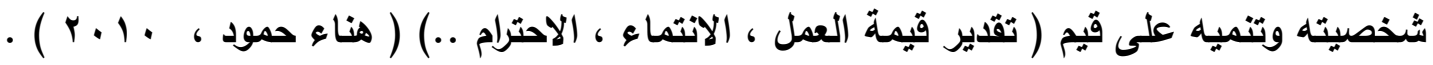
ويرى ( محمد قنديل) أن الاتجاه نحو تنمية الحس الوطنى يتطلب إكساب الطفل المهارات الحياتية المختلفة التي تعود على الطقل بفوائد عديدة منها ( تقدير الطقل لذاته ، الثعور بالمسؤولية ، احترام مشاعر الأخرين وأفكارهم ، المحافظة على ممتلكات الغير ، معرفة الحقوق والواجبات ) .

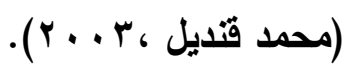


ويمكنتا الإثارة إلى تلخيص مجمل لأهم أهداف تربية الحس الوطنى في : - - تعريف الفرد بما عليه من حقوق وواجبات بصفته مواطنًا. - فهم الفرد واحترامه وتقديره للقوانين والأنظمة. - تعرف الفرد على القضايا والمشكلات التي يعاني منها المجتمع. - معرفة الفرد بوسائل المشاركة في النشاطات الوطنية والقومية. - فهم الفرد الحاجة للخدمات الحكومية والاجتماعية المرتبطة بحياته. - - توجه الفرد نحو المواطنة الصالحة.

- ت تمية الاعتزاز عند الفرد بالاتتماء والولاء للوطن و للأمة الإسلامية و العربية.( جودة أحمد ،

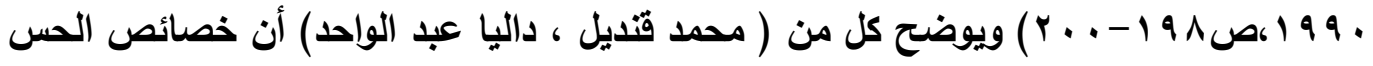

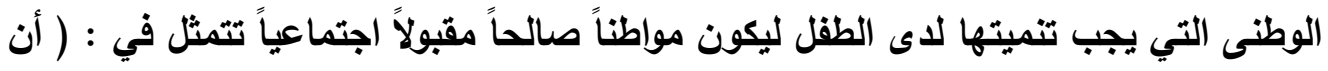
يتمتع بتحمل المسؤولية ، ويتوفر لايه المعارف والمهارات التي تؤهله لمواجهة المشكلات والتظلب عليها ، ، وأن يتوفر لايه مهارات التواصل ، ويقدر دلائل المساواة في الحقوق بين

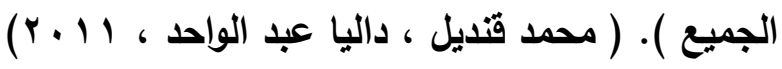

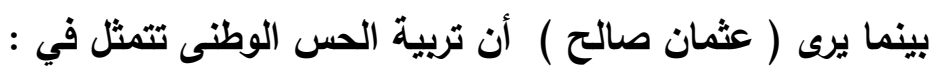
- الانتماء : شعور إيجابي ينبع من داخل المواطن يعمل بحماس واخلاص ويفتخر بوطنه. وللانتماء عدة أبعاد أهمها: الهوية تعنى سعى الفرد لتوطيد انتمائه بوطنه - - الجماعية : تثتمل على التعاون وتماسك الافراد والعمل على توطيد التفاعل المتبادل . - الولاء : هو أساس الالتزام ويدعم الروابط بين الجماعات ويؤكد الهوية الذاتية ويدعمها. - الديمقراطية : تتمثل في أساليب التفكير وتدل على ايمان الفرد بثلاث محاور مترابطة (تقدير

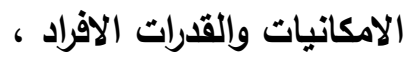

- - الحاجة الى التعاون مع الجماعة والتكيف معها، باتباع الطرق العلمية في التفكير). ( عثمان

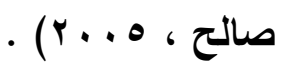

المحور الثاني : تأثير الأسرة والروضة على اكتساب الطقل مفاهيم الحس الوطنى :

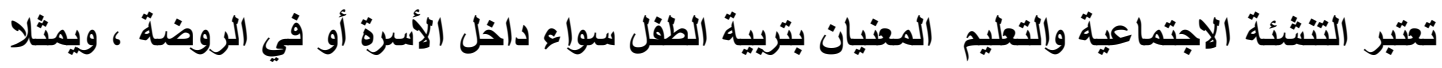

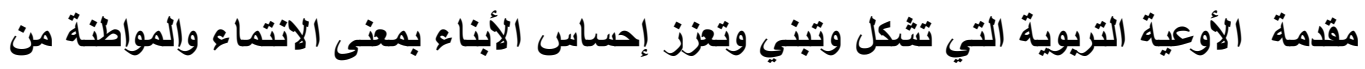

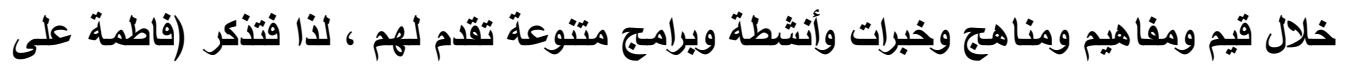


الثهراني) في دراسته التي هدفت إلى تقديم روئة مقترحة تتبنى الدور الذى يمكن أن تقوم به الأسرة

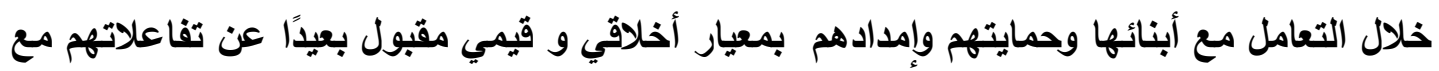
المؤثرات الخارجية مثل (شبكة الانترنيت)، والحد فيما ينتج عنها من سلبيات ، وذلك بغرس مفاهيم الحس الوطنى الرقمية في نفوس الأطفال بالثراكة مع المؤسسات المحلية والمجتمعية في ظل أمن فئن

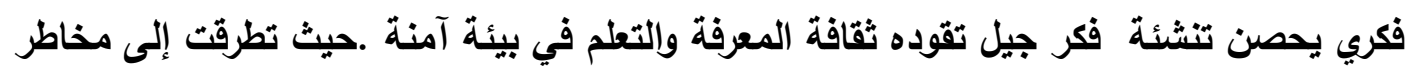
الثورة الرقمية وتأثيرها على الأفراد بالمجتمع السعودي ونادت بضرورة التقتين أو الحد منها للأطفال

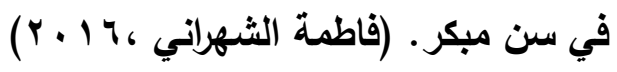
وهذا ما أكدت عليه دراسة (محمد عباس عرابي ) في دراسته التي هدفت الى التعرف على دور الأسرة والمدرسة في تنمية الوطنية والمواطنة في نفوس الأطفال ـ وأثشارت النتائج الى أن الوطنية

تمثل الجانب الفعلي للمواطنة والذى تحصل فيه النتائج المادية والملموسة التي تعود على الفرد

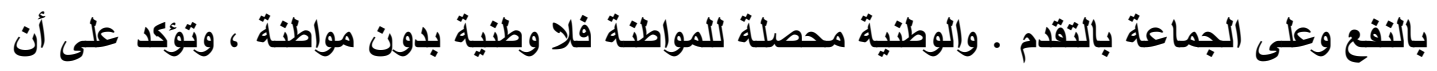

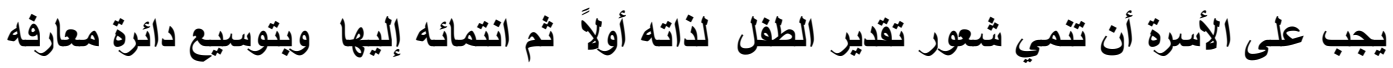
توازن بين ممارسته لمسؤولياته وادراكه لواجباته، لتعزيز الهذف العام في إعداد المواطن الصالح تنمية معرفته لحقوقه وتأديته ما عليه من واجبات تجاه مجتمعه ـ وأن يكون قادرًا على مواكبة

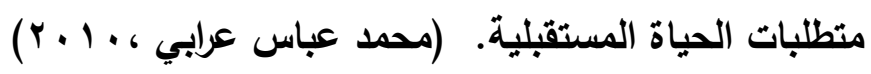

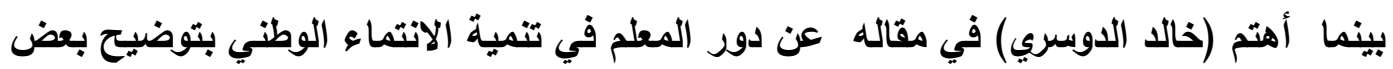

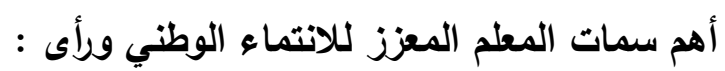
I. أن تتوفر لايه القدرة على إعداد أطفال معتزين بوطنهم ويولاة أمرهم ، بجانب تمتعهم بالقدرة

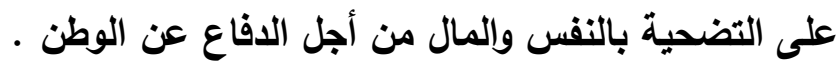

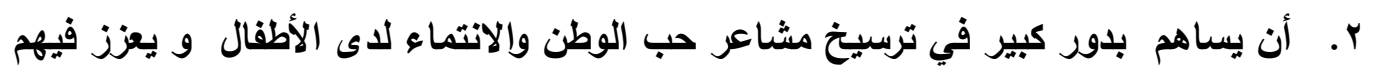

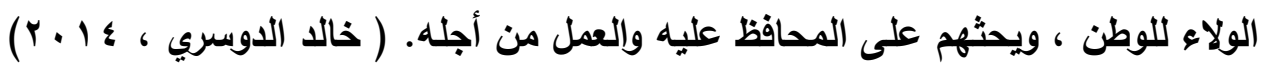

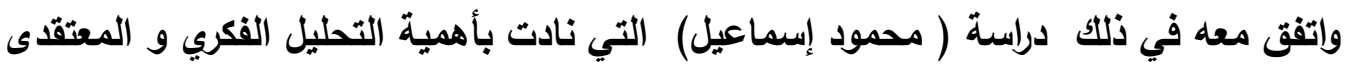

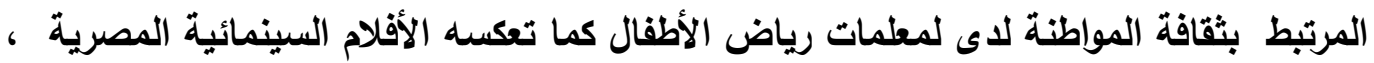

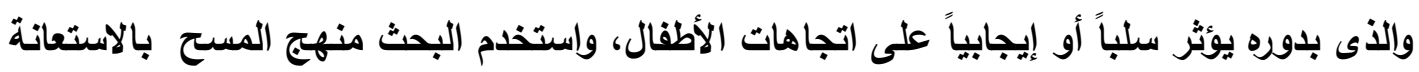

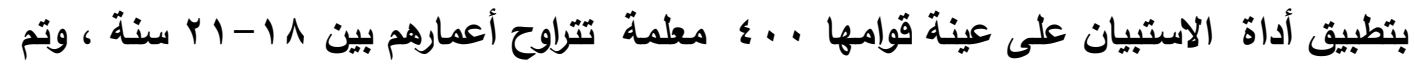
توزيعهم بالتساوي بكليات رياض الأطفال في (جامعة بورسعيد - جامعة عين شمس) في محافظهات القاهرة ويورسعيد من معلمات رياض الأطفال. النتائج: خلصت الدراسة إلى ارتفاع نسبة من بنديل 
يشاهدون الأفلام السينمائية من معلمات. مما يؤثر في اتجاههم نحو المواطنة ودرجاتها ومستوى الثقافي لايهن مما ينعكس على تشكيل معتقات الطفل الوطنية ـ (محمود إسماعيل ، ؛ 1 ـ ب)

المحور الثالث : دمج مفاهيم الحس الوطنى في أنشطة تعلم طقل الروضة: وأكدت ( رانيا عبدالعزيز) في دراستها التي هدفت دراسة أثر برنامج ترويحي باستخدام الألعاب الشعبية على الانتماء ومفاهيم الحس الوطنى لطفل الروضة من(ه - ؟)سنوات .على أهمية الألعاب في ترسيخ القيم والاسس الحضارية بما يتلاعم مع ثقافة المجتمع وتتمية مفاهيمه عن الانتماء والمواطنة ـ وتنوعت الباحثة في استخدام أدوات البحث بين مقياس لتقدير الانتماء لدى الأطفال بجانب بطاقة الملاحظة لقيم المواطنة. وأسفرت نتائج الدراسة الى التأثير الإيجابي على تقدير الانتماء وتتمية مفاهيم الحس الوطنى • وأوصت بضرورة تصميم برامج ارشادية لمعلمات الروضة لإبراز أهمية دمج الانتماء والمواطنة في جميع الأنثطة التريوية المقدمة للأطفال. (رانيا عبدالعزيز $(r+1) \cdot$ ويتبنى البحث الحالي بما اتفق عليه كل من ( وثيقة المعايير القومية لرياض الأطفال جمهورية مصر العربية ) ، Richard Weston and others ) المواطنة كأحد محاور المفاهيم الاجتماعية وتدريسها في ضوء الأهداف الداعمة لإكساب الطفل مفاهيم الحس الوطنى و مبادئ الايمقراطية كأحد مجالات التعلم ويمكن إيجازها في البنود التالية : •يمارس الطقل مشاعر الانتماء للوطن مثل (اشخاص- أماكن - نظم) ميظهر مشاعر طيبة تجاه رموز الوطن ( مثل العلم - النيل - القائد) ميراعي الآداب العامة مثل السلوك - الحوار - المظهر - العلاقات) ميتبع القوانين و القواعد مثل ( النظام - المرور - النظافة) ميلتزم بالقيم الاجتماعية الداعمة للتقدم و السلام الاجتماعي مثل ( التسامـح- التعاون - المبادأة تحمل المسؤولية- المساواة ) ميتعرف اهمية المهن و الادوار المختلفة و الملكية العامة ). (وثيقة المعايير القومية لرياض

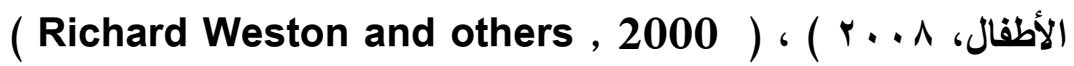
• مفاهيم الحس الوطنى للطقل وواقع المجتمعات: . استهدفت بعض الدراسات برامج رياض الأطفال بالمملكة العربية السعودية بالتحليل للمضمون القيمي للمواطنة بهدف تحديد مدى مراعاة أنشطة رياض الأطفال لمفاهيم الحس الوطنى من وجهة 
نظر المعلمات ـ فقد تمكن الباحث من استخلاص قائمة مفاهيم الحس الوطنى المناسبة للطقل

بالإضافة الى عرضة للقيم المتوفرة بالمنهج كالاتي ( المبادأة - الأمن - تحمل المسؤولية العدل..... الانتماء الوطني ). وأكلات الدراسة على أن الأنثطة التربوية في رياض الأطفال سواء كانت ( المنهجية والللامنهجية) بمرونتها تسمح للمعلمة بتنمية مفاهيم الحس الوطنى لاى الأطفال . ويرى الباحث ضرورة أن تخضع للإشراف الجيد عليها، وإجادة اختيار العناصر الفعالة، بالإضافة إلى التتظيم والتخطيط الكافي لها قبل القيام بها حتى لا تفشل في تحقيق هدفها التريوي والتعليمي

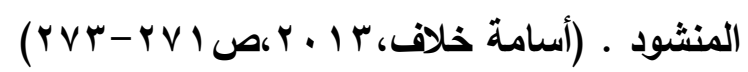

• خبرات ومفاهيم تثرى ثقافة الحس الوطنى لطقل الروضة :

فقد تعددت الدراسات في هذا المجال فمنها ما ركز على إن الوضع المثالي لهو ادخال ثقافة حقوق الانسان ضمن المناهج الدارية ، وذلك بهدف جعل مبادئ حقوق الطقل وواجباته ذات معنى وتؤكد

على ضرورة تنميتها لصفار الأطفال ، موضحاً أن لايهم القدرة على فهم المبادئ وممارستها ـ ويتعريف الأطفال مفاهيم حقوق الانسان من خلال تدريس مناهج متدرجة ومترابطة تتضمن المستويات العمرية المختلفة (مرحلة الطفولة المبكرة ، مرحلة الطفولة المتقدمة ، والمراهقة ) . والاهتمام بتضمين قيم وممارسات (المواطنة ، التمييز بين الحقوق والوجبات، واحترام الاخرين وتبادل الآراء ،الالتزام بقواعد وآداب السلوك القويم ). ( سيرجيو فيرا دي ميلو ، 9، . . . ) ) بينما ركزت الأبحاث الأخرى في تناول نوعية الأنشطة التريوية التي يمكن أن تنمى قرات الطقل على اكتساب القيم وهذا وتؤكد دراسة ( غيداء ) عليه لإمكانية تنمية الحس الوطنى للطفل من خلال الخبرات والأنشطة التريوية التعليمية التي تركز على ( المشاركة في الحوار، التعبير عن المشكلات اليومية وتقديم حلول لها ، الاهتمام بالعمل التعاوني بين الأطفال واحترام الأخرين واتباع النظام والمساواة). الانتماء للوطن ، احترام الأطفال للقانون وقواعد اللعب وحقوق الأخرين ).

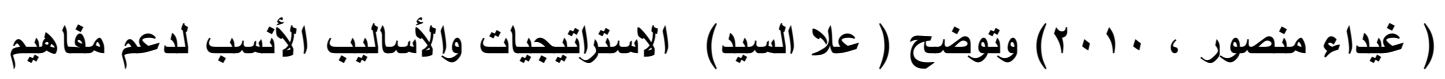
الحس الوطنى للطفل بشكل محبب في دراستها والتي هدفت إلى إكساب الطفل القيم والمبادئ والمفاهيم التي تساعد على تنمية "مفهوم المواطنة والتحقق من مدى فعالية برنامج النشاط التمثيلي المسرحي في تنمية مفهوم المواطنة لأطفال الروضة. و استخدت الدراسة المنهج التجريبي لمناسبته لطبيعة هذه الدراسة و اشتملت عينة البحث أطفال روضة (ع-7)سنوات ، مستخدمة مقياس "مفهوم المواطنة" المصور لطقل الروضة ، استمارة ملاحظة سلوكيات الطقل حول أبعاد 
مفهوم المواطنة ، استمارة الحالة الاجتماعية والاقتصادية والثقافية للأسرة. و توصلت الباحثة بعد تطبيق البرنامج إلي وجود فروق دالة احصائياً بين المجموعات التجريبية الثلاث ، و المجموعة الضابطة لصالح المجموعات التجريبية الثلاث مما يؤكد علي فعالية برنامج النشاط التمثيلي المسرحي في تنمية مفهوم المواطنة لأطفال الروضة هذا ما استفاد منه البحث الحالي في تنوع أنشطة البرنامج بجانب استخدام المقياس المصور أداة

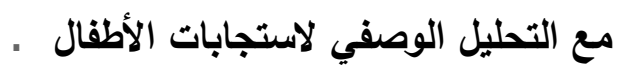
أدوات البحث واجراعاته: أولاً :إعداد قائمة بالمفاهيم الخاصة بالحس الوطنى : .

تمت صياغة مقياس الحس الوطنى في ضوء نمط الاختيار من متعدد مصاحب بصور ايضاحية لكل بند في المقياس • وتقديمها على هيئة مواقف وأنشطة للأطفال ، وقد بلغ عدد التساؤلات ب ا سؤالاً ووزعت على القيم المحدة بالمقياس وهى ( الانتماء للوطن - التمييز بين الملكيات العامة والخاصة - تقدير العمل ( مهنة الشرطي). كالآتي: (جدول ا ) عرض مؤشرات المقياس في ضوء مفاهيم الحس الوطنى:

\begin{tabular}{|c|c|c|}
\hline مجموع المؤشرات بكل بعد & فقرات ومؤثرات الأداء بالمقياس & مفاهيم الحس \\
\hline ؛ ؛ دؤثرات & 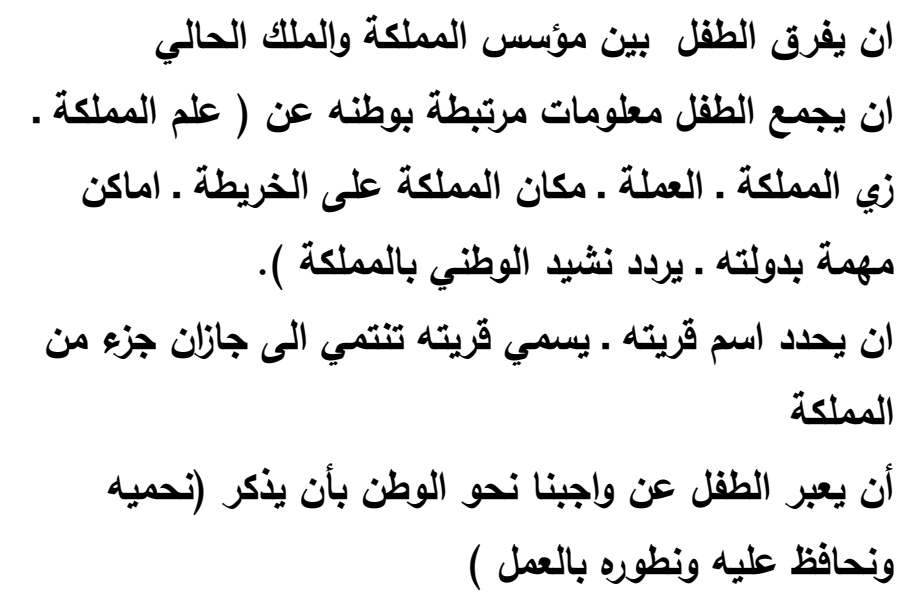 & الانتماء \\
\hline ع مؤشرات درجات & 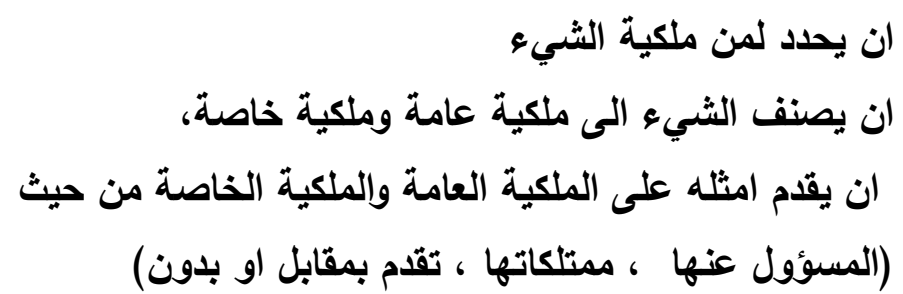 & العامة والخاصة \\
\hline
\end{tabular}




\begin{tabular}{|c|c|c|}
\hline & 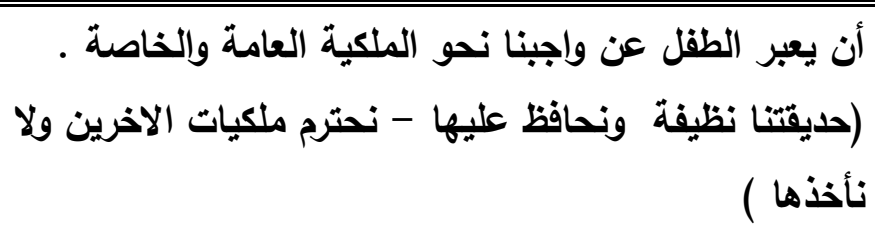 & \\
\hline ؛ ؛ مؤشرات & 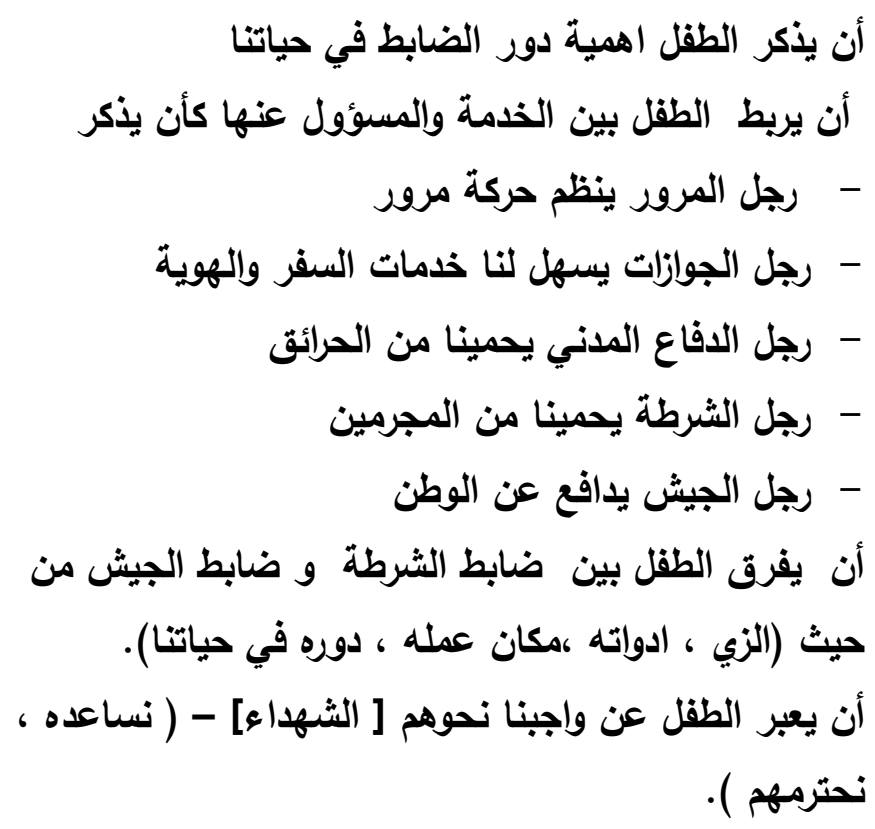 & تقدير قيمة \\
\hline r r امؤثر & & للمؤشرات المجوع الكلى \\
\hline
\end{tabular}

وقد حدت الباحثين درجة واحدة لكل فقرة إذا كانت الاجابة صحيحة وصفراً إذا كانت الإجابة خاطئة

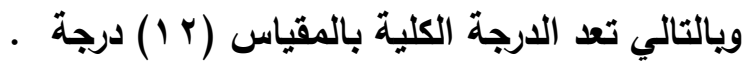

\section{ثنانياً اختيار عينة البحث ووصفها :}

تم اختيار عينة البحث بطريقة عشوائية لأحد قاعات روضة الحسيني التابعة لمدينة جازان التعليمية. وتم التطبيق على عينة من الأطفال بالمستوى( الثالث) وعددهم (ه 1) طفلاً. وتتراوح أعمارهم من (0-7 (7) سنوات. ثالثاً :إعداد أدوات البحث وضبطها: *اعداد مقياس مصور للحس الوطنى ( الانتماء - تقدير الملكية العامة والخاصة - تقدير العمل). 
*اعداد برنامج قائم على الأنثطة التريوية لتنمية مفاهيم الحس الوطنى تمثلت في (الأنشة: اللغوية - القصصية - القنية - الحركية - ايحثية وحلقات مناقشة ). باستخدام استراتيجيات تعلم متنوعة مثل ( العصف الاهني ، الحوار و المناقثة ، المحاكاة، الأداء العملي ، الترديد والالقاء). وتم تطبيق أنشطة البرنامج على عينة البحث باستخدام عينة واحده ( التصميم التجريبي ذو العينة الواحدة) طبق عليها المقياس مرتين ( قبلي ويعدى)

$$
\text { لنفس العينة . }
$$

\section{نتائج البحث وصفها وتحليلها وتفسيرها:}

أولاً : عرض النتائج المتعلقة بكل هدف من أهداف الحس الوطنى وتفسيرها في ضوء لاراسات السابقة:

باستخدام أسلوب تحليل الوصفي لنتائج الاطفال كما تتضح بالشكل التالي ( ) في ضوء لابعاد المحددة بالمقياس نجد أن:

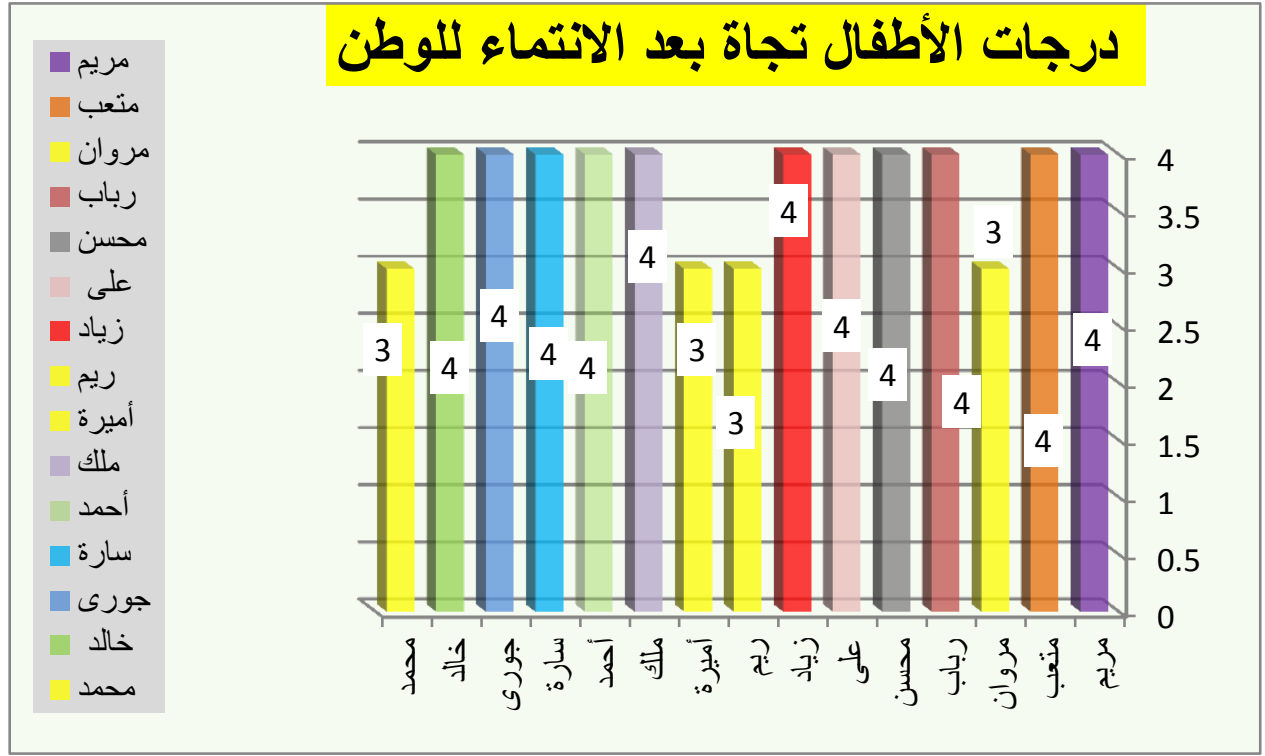

تثير استجابات الاطفال كما اتضحت بشكل (1) تجاه (مفهوم الانتماء ) كأحد القيم الاعمة لمفاهيم الحس الوطنى أنه بالرغم من تمتع الاطفال بخبره سابقة بالمفهوم الي أن احدى عشر طفلا أي بما يعادل هv\%تمكنوا من ذكر اسم الملتك الحالي للمملكة بجانب تمييز العلم والوانه وذكر تفاصيله من بين الاعلام الأخرى وكذلك التعرف على عملة المملكة والزي الرسمي بها وترديد النشيد الوطني وتمبيز مكانها على الخريطة ، بالإضافة 
الى ذكر أي محافظة يتبعونها وما دورهم نحو وطنهم، فقد ذكروا [ نحميه ونحافظ عليه ]. وهذا ما يؤكد عليه (محمد قنديل،ب . . r) أن الاتجاه نحو تنمية الحس الوطنى يتطلب إكساب الطفل المهارات الحياتية المختلفة والمعارف المرتبطة بمجتمعه و رموزه ، إلا أن أربعة منهم \} ريم ـ محمد ، مروان ـ اميره \{ لم ينتبهوا الى التمييز بين مؤسس المملكة والملك الحالي للملكة بجانب عدم قرتهم على تحديد و ذكر اسم قريتهم التي يعيشون فيها والمحافظة التي تنتمي اليها وذكروا [ نعيش في المملكة العربية السعودية - جازان] • ولم يتمكنوا من ذكر العلاقة بين مدينة جازان والمملكة، بالإضافة الى عدم انتباههم لترتيب الملوك من الأقدم للأحدث ، أي بما يعادل هr\% من اطفال العينة كان أدائهم شبه

كاملا .

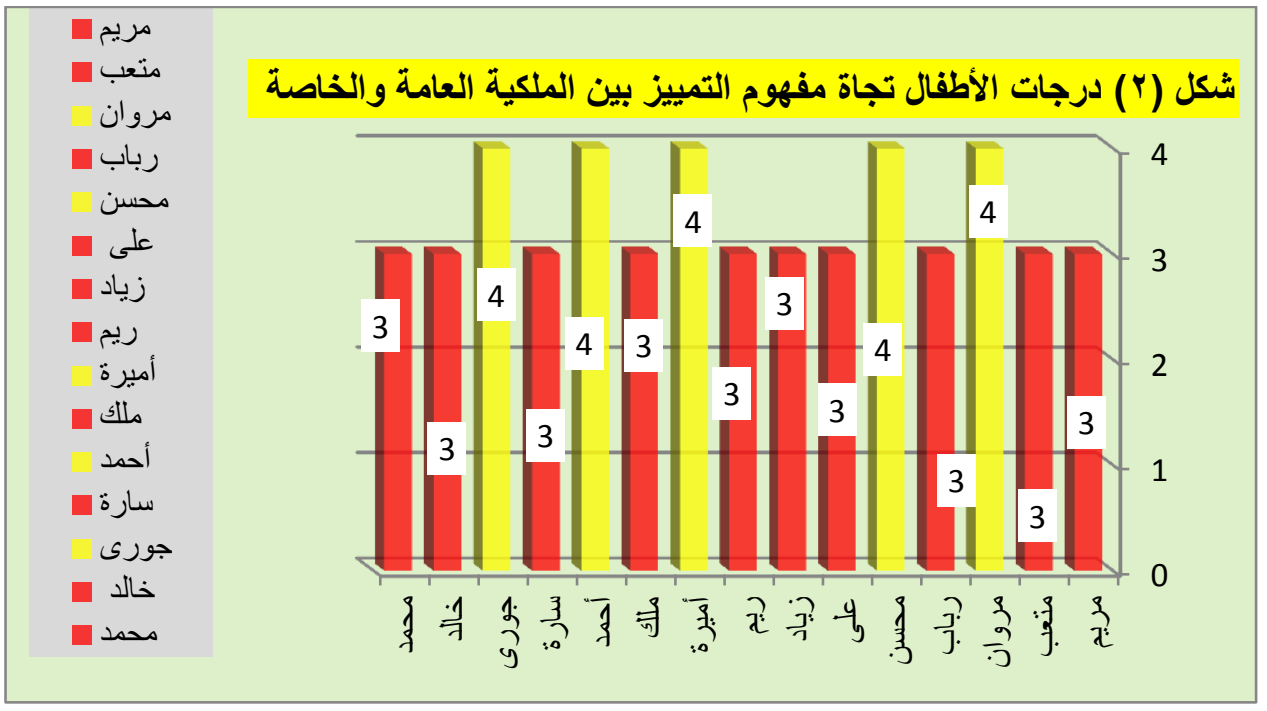

• ويتحليل نتائج الاطفال تجاه مفهوم التمييز بين الممتلكات العامـة والخاصـة كما يتضـح بالثكل السابق (Y) فقد اسفرت النتائج الى تمييز خمسـه فقط من الاطفال أي مـا يعادل • r من أطفال العينة ووصفه بالأداء الكامل فقد نمت قدرتهم على تعرف مفهوم ( التمييز بين الملكيـة العامـة والخاصـة ) . وتحديد ملكية الثـيء وتصنيفه (حكومي . افراد) فذكروا ( القلم حقي و الكرسي حق الروضـة ) وذكر الامثلـة المختلفة للملكيـة العامـة عن غيرها (حديقة - مستشفى - روضـة ) مبررين ذلك عندما تمكنوا من الربط بين الثيء والمسؤول عنه . . وكذلك كيفية الحصول عليه (هل يقدم لـه مـال ليقتيه أم بدون) ـ فهذا ما أوضحته العديد من الدراسـات مثل (وطفه أسعد ، 999 1 ) التي أكدت أن تنشئة الاطفال علي المفاهيم في سن مبكرة تكون اكثر ثباتاً ، وتثكل معيار سلوك الفرد كـاحترام الممتلكـات العامـة و الحفـاظ عليهـا كمـا اسفرت التتائج عن ترديد الاطفـال 
لمفردات لغوية تدل على قدرتهم على التمييز بين الملكية العامـة والخاصـة مثل (حاجتي احافظ عليه حقي) ، (حاجات الدولة نحافظ عليها كلنا ). بينما عشرة الاطفال الاخرين وصف أدائهم بشبة كامل أي بنسبة ( • \% ) من أطفـال العينة لإخفاقهم في عدم انتباههم لتحديد ملكية الشيء ( حكومي ـ اهلي)، ويناء عليه اخفقوا في تصنيفه الى ( ملكيـه عامـه وخاصـه ممـا يترتب عليـه ضـف القدرة على التمييز بين ملكيـة الاشـياء تتوقف على القابل المادي والمؤسسة المسؤولة عنها ) .

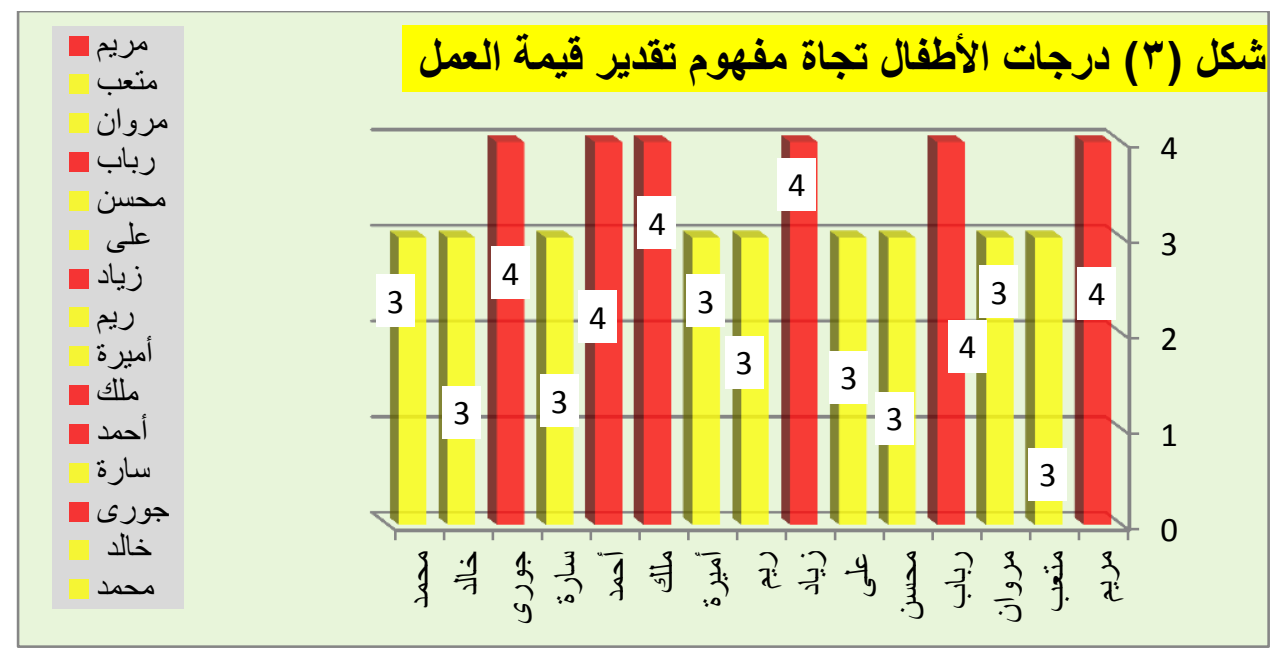

• كما أسفرت نتائج الاطفال بالشكل السابق (r) إلى أن ستة اطفال من أطفال العينة تمكنوا من الأداء الكامل بما يعادل بنسبة .؛\% ونمت قدتهم للتعرف على مهنة الضابط فكروا : (عسكر ). ووصف الأدوار و الخدمات المختلفة له في المجتمع ( رجل الدفاع المدني نتصل عليه ^9 9 ) ـ كذلك تمكنوا من الربط بين الخدمة والمكان المسؤول عن تقديمها و كذلك تحديا القائم عليها فقد ذكروا ( عسكر ع الحدود يحمى وطنا ) .بالإضافة إلى استخدام بعض الكلمات التي عبرت عن ادراكهم لتنوع دور الضابط في حياتنا بين رجل الشرطة والدفاع المدني ورجل المرور والجيش، وذكروا الخدمات التي يقدمونها لنا، بالإضافة الى تمكنهم جميعاً لذكر [ المرابطين على حدونا يحاريون]. بينما لم يتمكن الأطفال التسعة الآخرين من ملاحظة الفرق بين رجل الجوزات والثرطي من حيث الخدمة المقدمة ، بالإضافة إلى إغفالهم دورنا نحو الثهيل وما يمكن أن يقدمه له ولأسرته ، بالرغم من تجاويهم خلال ممارسة الأنشطة التربوية.

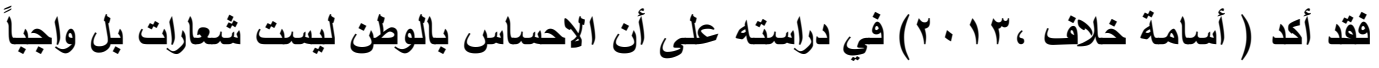


وسلوك يدل على تقدير الفرد بأهية دوره كمواطن مؤديًا لواجباته و متمسكًا بحقوقه والدفاع

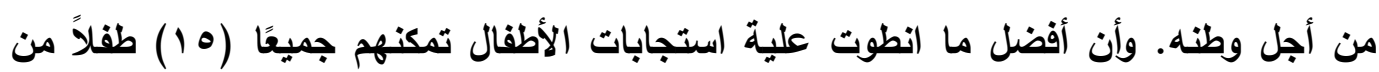
تحديد أدوات ضابط الثرطة والجيش والاختلاف الذي بينهم وذكر مكان عملهم. وبهذا تتضح قدرة الأطفال على تقيريهم قيمة العمل في الحياة. أي بنسبة ـ ؟ \% اداء شبه كامل. - تعليق عام لنتائج الأطفال على مقياس مفاهيم الحس الوطنى :

شكل (๕)

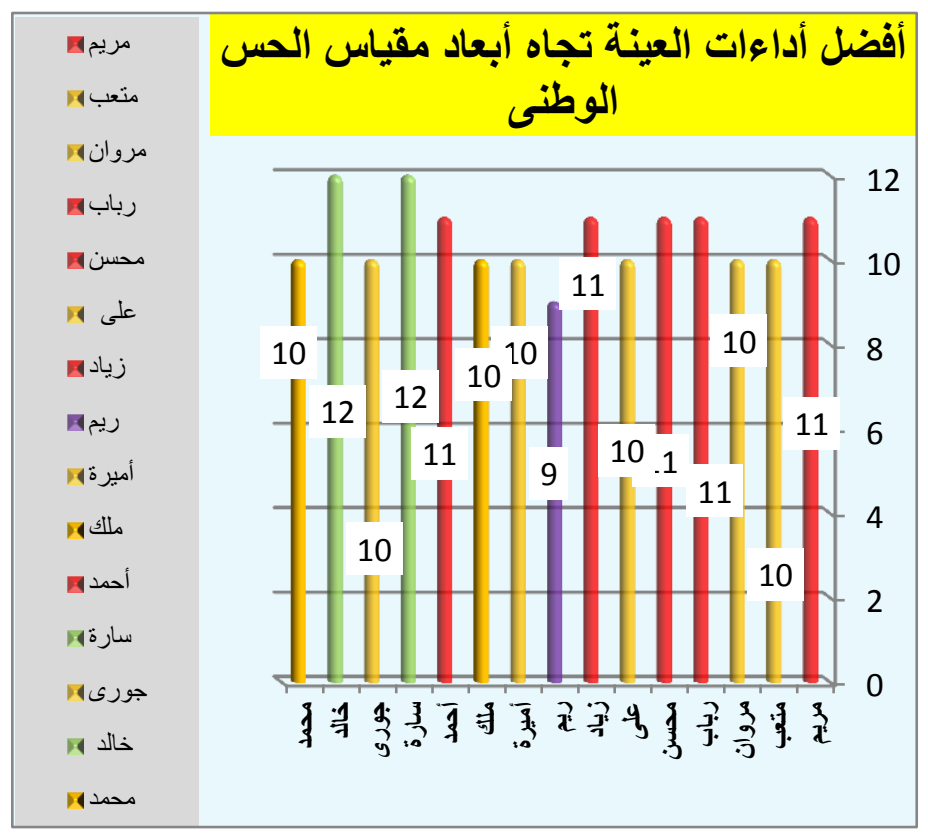

شكل (0)

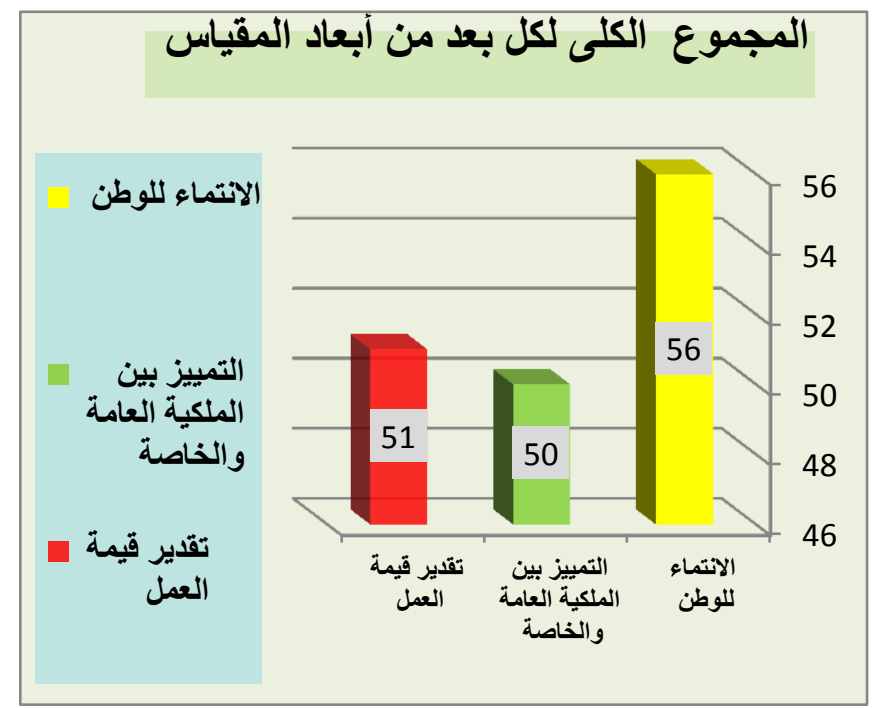

فقد أسفرت نتائج الأطفال كمـا (تضـح بالثكل( ؛) على أن أداءات الأطفال تجاه مقياس الحس

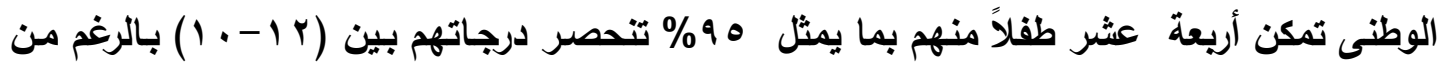


وجود فروق طفيفة في الأداء بينهم إلا أن أفضل أداعات الأطفال على الإطلاق الأطفال(خالد ،سارة ) لتميزهم بالانتباه والقدرة على الملاحظة وتمتعهم ببعض الخبرات السابقة ، بجانب السرعة في الأداء والتفاعل خلال الأنثطة التريوية كما اتسم ادائهم بالحرص على نقل خبرات للأخرين .

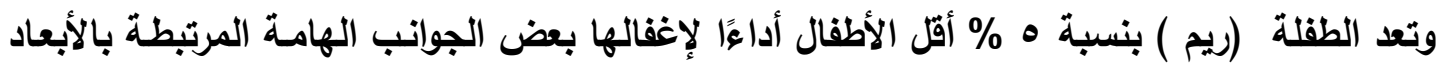

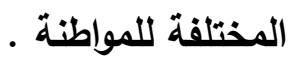
كما يتضح من الثكل (ه) أن أفضل المفاهيم أداءًا على الأطلاق خلال ممارسة الأنثطة التريوية المختلفة المتعلقة بهدف الانتماء للوطن في الترتيب الأول ، ويليها في الترتيب الثاني هدف تقدير قيمة العمل والمهن المختلفة بالمجتمع بـالرغم من التقارب بين معدل الدرجات بينها ويبن بعد

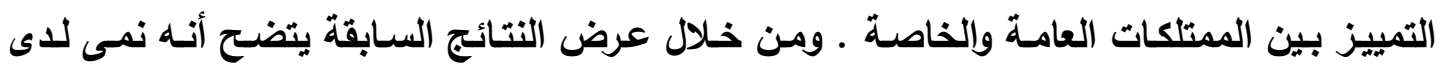
الأطفال القدرة على ممارسة الانتماء والاعتزاز بالوطن وتقدير دور جنوده في الحفاظ على أمنـه بجانب المحافظة على ممتلكاتهه وتقدير ملكيات وخصوصيات الاخرين ـ وهذا يعنى قبول الفرض الأول لابحث والذى ينص على أنه يستطيع طفل الروضة ممارسة مفاهيم الحس الوطنى (الانتماء للوطن ، تقدير المهن والعمل ، التمييز بين الممتلكات العامة والخاصة).

عرض النتائج المتعلقة بفروض البحث المعالجة احصائياً و الذى ينص على أنه:

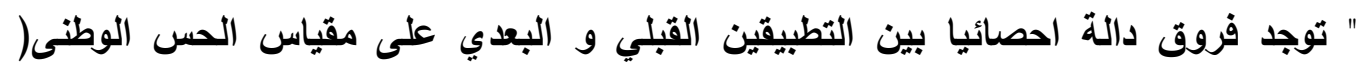

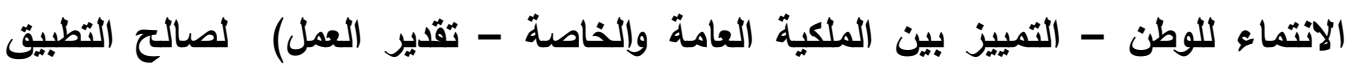
ويتم عرض نتائج الفرض الثاني باستخدام اختبار ويلكوكسن للرتب : ويستخدم هذا الاختبار في التصميمات البحثية التي تجرى فيها المقارنة بين عينتين مترابطتين (قياسـان لعينتين واحدة من الأفراد ) وهو يقابل اختبار ت لعينتين مترابطتين في الاحصاء

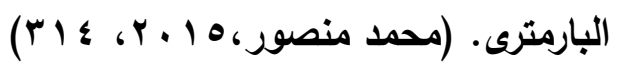


جدول(ץ ) يعرض نتيجة اختبار ويلكوكسن للتب لأداعات الأطفال تجاه مقياس الحس

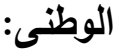

\begin{tabular}{|c|c|c|c|c|}
\hline مستوى & $\mathbf{Z}$ & العدد & البيان & المفاهيم \\
\hline$\ldots 0$ & \multirow{8}{*}{$\begin{array}{l}\text { I.v } \\
\text { or }\end{array}$} & $9 \leq$ & القبلي > البعدي السالبة & \multirow{2}{*}{ الانتماء } \\
\hline احصائياً & & - & القبلي > البعدي الموجبة & \\
\hline$\ldots 0$ & & Ir. & القبلي > البعدي السالبة & \multirow{2}{*}{ الملكية العامة بين } \\
\hline احصائياً & & . & القبل > البتب الموجبة & \\
\hline$\ldots 0$ & & $11 \varepsilon$ & القبلي > البعدي السالبة & \multirow{2}{*}{ تقدير قيمة } \\
\hline احصائياً & & • & القبلي > البوجبة البعدي & \\
\hline$\ldots 0$ & & qr & القبلي > البعدي السالبة & \multirow{2}{*}{ المجموع } \\
\hline الحصائياً & & • & القبل > البتب الموجبة & \\
\hline
\end{tabular}

من الجدول الموضح أعلاه يتضح أن هناك فروق دالة احصائيا عند مستوى دلالة ه. . . بين درجات الأطفال في التطبيقين القبلي والبعدي لقيم المواطنة لصالح التطبيق البعدي

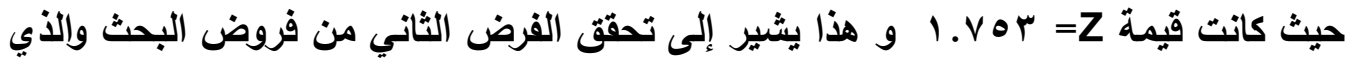
نص على أنه " يوجد فروق دالة احصائيا بين درجات الأطفال في التطبيقين القبلي والبعدي على مقياس مفاهيم الحس الوطنى لكل من الأبعاد الثلاثة ( الانتماء للوطن - تقدير قيمة العمل - التمييز بين الممتكات العامة والخاصة ". ويمكن للباحثين أن تعزيا نتيجة المقياس

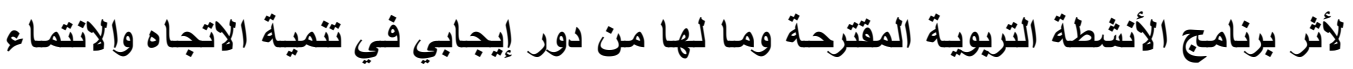


للـوطن والاعتزاز بـه ويتـاريخ تأسيس المملكة و التعرف على ملـوك المملكة ، وتقدير مهنـة الضـابط التـي انتبـه الأطفـال أن لهـا أدوار مختلفـة في المجتمـع والتأكيد على الفـرق بـين الشرطي داخل الوطن وعلى الحدود وفائدة دورهم للمجتمع. بالإضـافة الى أثر الأنشطة في تمييز الممتلكات العامة والخاصة. التوصيات والمقترحات : في ضوء النتائج التي توصل اليها البحث يمكن التوصية بما يلى : 1 - ضرورة تطوير المناهج المقدمة لطقل الروضة في ضوء ابراز مفاهيم الحس الوطنى المؤثرة في المجتمع وريط خبراته المتعلمة بما يتوافق مع المتغيرات المجتمعية التي تحيط به وتثنكل فكره وشخصيته. r-اعداد برامج الأنشطة التريوية المتكاملة والأدلة الارشادية للقائمين على تعليم طقل الروضة تستهدف تنمية مفاهيم الحس الوطنى المرتبطة بحقوقه وواجباته نحو الوطن. ب-ضرورة تبنى مشروع قومي على مستوى المملكة لصياغة المعايير القومية المرتبطة بمرحلة رياض الأطفال في ضوء التفيرات العالمية .

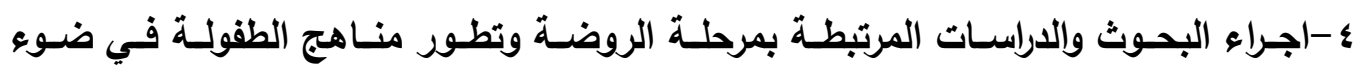
المتغيرات العالمية لما لها من تأثير بالغ في تثكيل شخصية الطقل المستقبلية . ه-دراسة أثر برنامج المهارات الحياتية لتنمية مفاهيم الحس الوطنى لطقل الروضة . צ- اقامة مشاريع في الروضات صغيرة للأطفال مثل مهنتي مستقبلياً ( الثرطي الصغير ... ) بالتعاون مع أولياء الأمور والمؤسسات بالمجتمع المحلى • V-اعداد مشروع تطبيقي للبحث لتريب معلمات الروضة لتعميم الاستفادة من تطبيق مفاهيم الحس الوطنى لتنشئة الطقل عليها لرفعة الوطن . 1-تصميم برمجيات خاصة بالطقل تتبنى فكرة مجالات العمل لمهنة الشرطي ( رجل المرور ، الجوزات ، الجيش ، الـفاع المدني) للتعرف على طبيعة المهنـة وأدواتها والجهـة المسؤولة 


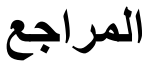

\section{أولاً : المراجع العربية}

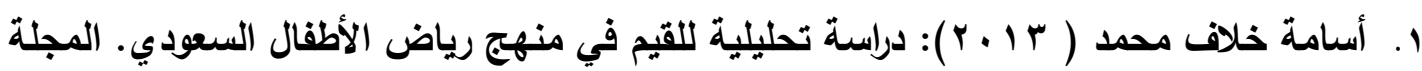
الدولية التريوية المتخصصة ـ المجلد (ץ) العدد(ץ). السعودية.

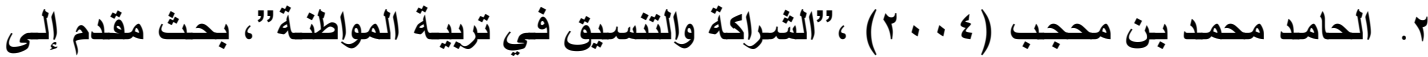
اللقاء الثالث عشر لقادة العمل التربويين المنعقد في المملكة العربية السعودية، مجلة المعرفة،

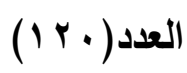

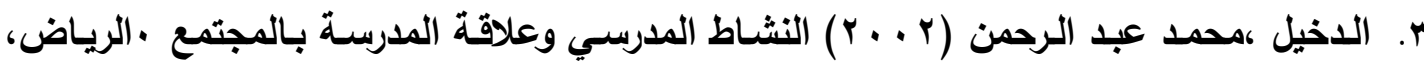
الار الخريجي للنشر

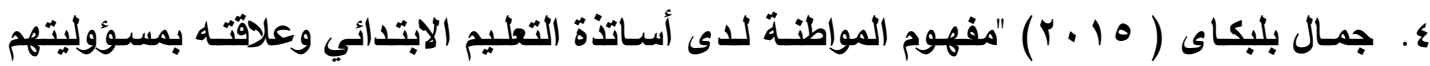

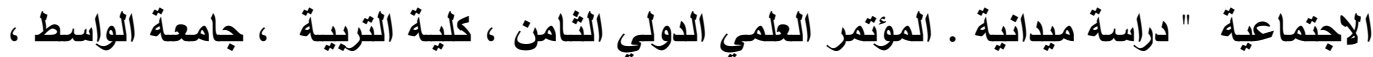

العراق

ه. جودة أحمد سعادة ( •99 19): مناهج الداسات الاجتماعية ، دار العلم للملايين ، بيروت.

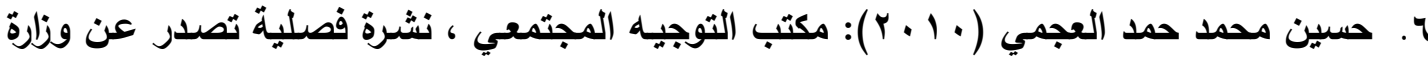
الأوقاف والثؤون الإسلامية، دولة الكويت .

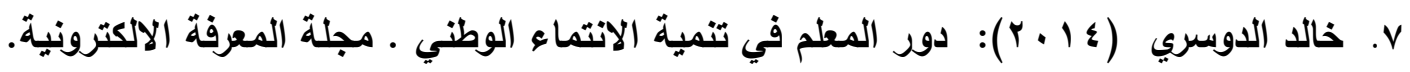
http://www.almarefh.net/show_content.php. am : 11-18-1-2016

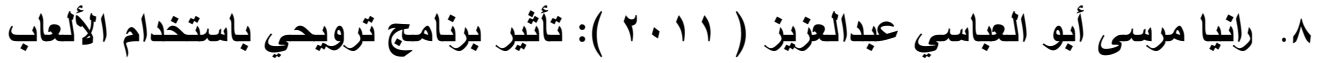
الثعبية على الانتماء ومفاهيم الحس الوطنى لطفل ما قبل المدرسة ـ ـ رسالة دكتوراه ، كلية التربية الرياضية للبنات ، جامعة الزقازيق.

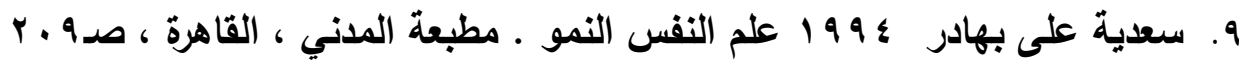

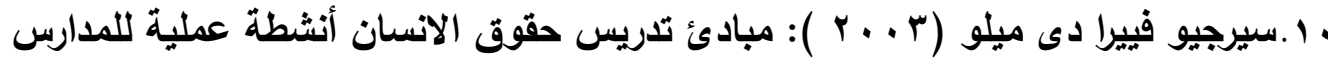

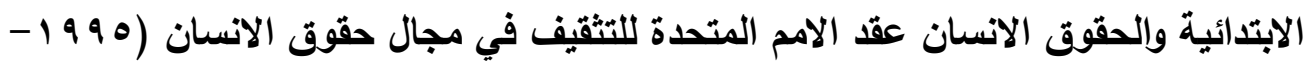

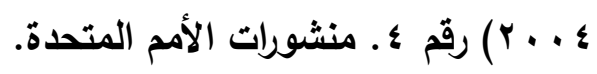
11 1.عبد الدايم عبد الله ( 1991 ):دور التربية والثقافة في بناء حضارة إنسانية جديدة ، القاهرة

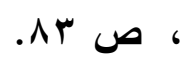
r r.عبد الله المجيدل 1 ـ ب التربيـة المدنيـة: دراسة في أزمة الانتماء والمواطنة في التربية العربية . 


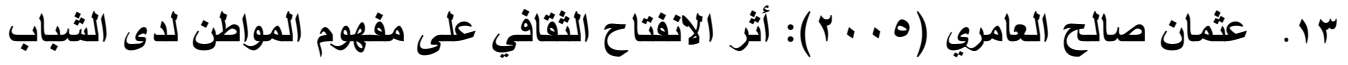

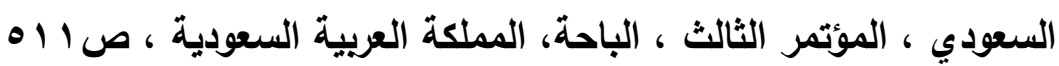
http://edusocio.net/index.php

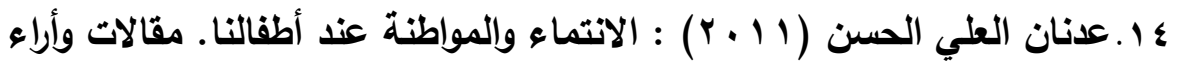
http://www.qenshrin.com/details.php?id=29305En-pm:5/10-11-2016

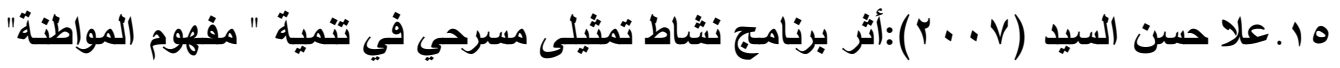
لأطفال الروضة . رسالة دكتوراه، كلية رياض الأطفال ، جامعة القاهرة . 17 المدرسة ، كلية التربية ، الخرطوم.

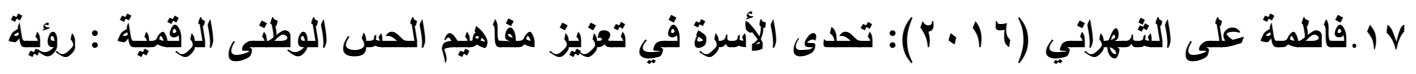
مقترحة ـ الملتقى العلمي " دور الأسرة في الوقاية من التطرف " ، كلية العلوم الاجتماعية

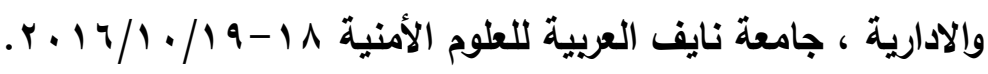

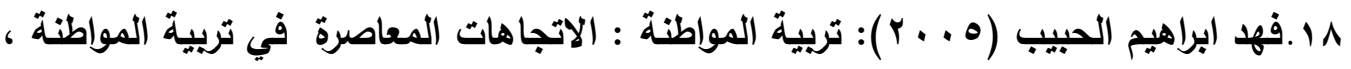
جامعة الملك سعود ، الرياض ، السعودية.

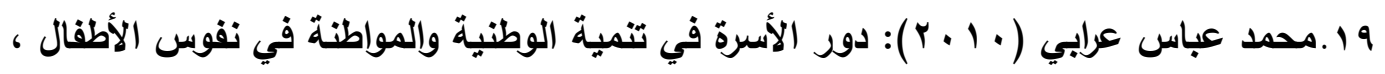
مركز البحوث واللاراسات الاسلاهي، القاهرة.

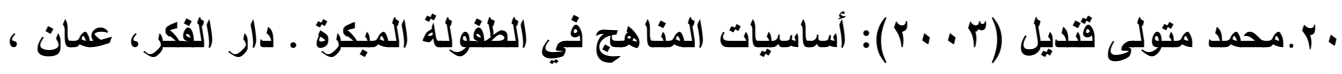
الأردن

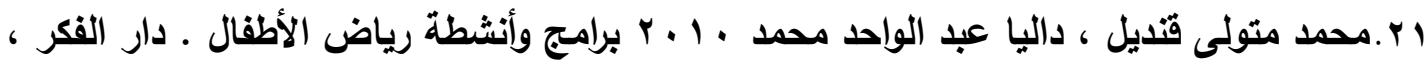
عمان ، الأردن. r. r. محمود حسن إسماعيل (؟ 1 • r): .إدراك عينة من معلمات رياض الأطفال لثقافة المواطنة كما

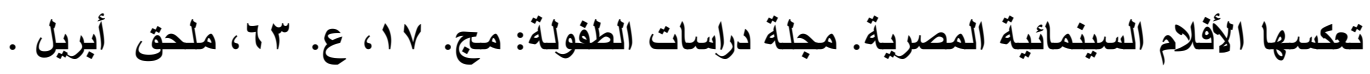

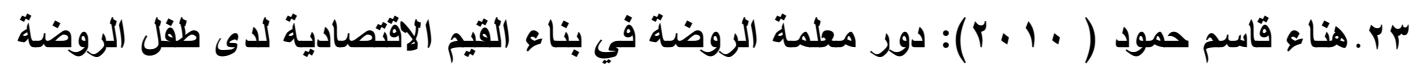
ما بين (ه- (؟) سنوات دراسة ميدانية في رياض الأطفال بمدينة دمشق ، جامعة دمشت ، كلية

$$
\text { التربية ، سوريا. }
$$

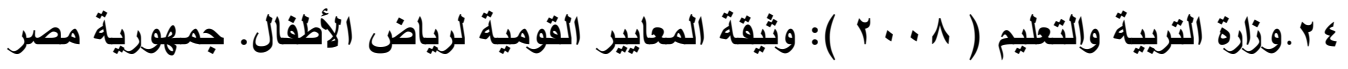
العربية هץ.وطفة ، علي أسعد ، ( 1999 ) ) بنية السلطة وإشكالية التسلط التربوي في الوطن العربي ،

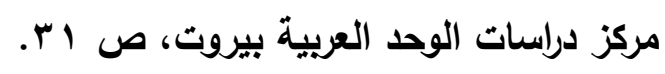




\section{المراجـع الأجنبيـة}

Richard Weston and others (2000):History - Social Science Content

Standers For California Public School (Kindergarten Through Grade

Twelve ). California State Board of Education - CSEA members ,p3-4

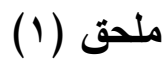
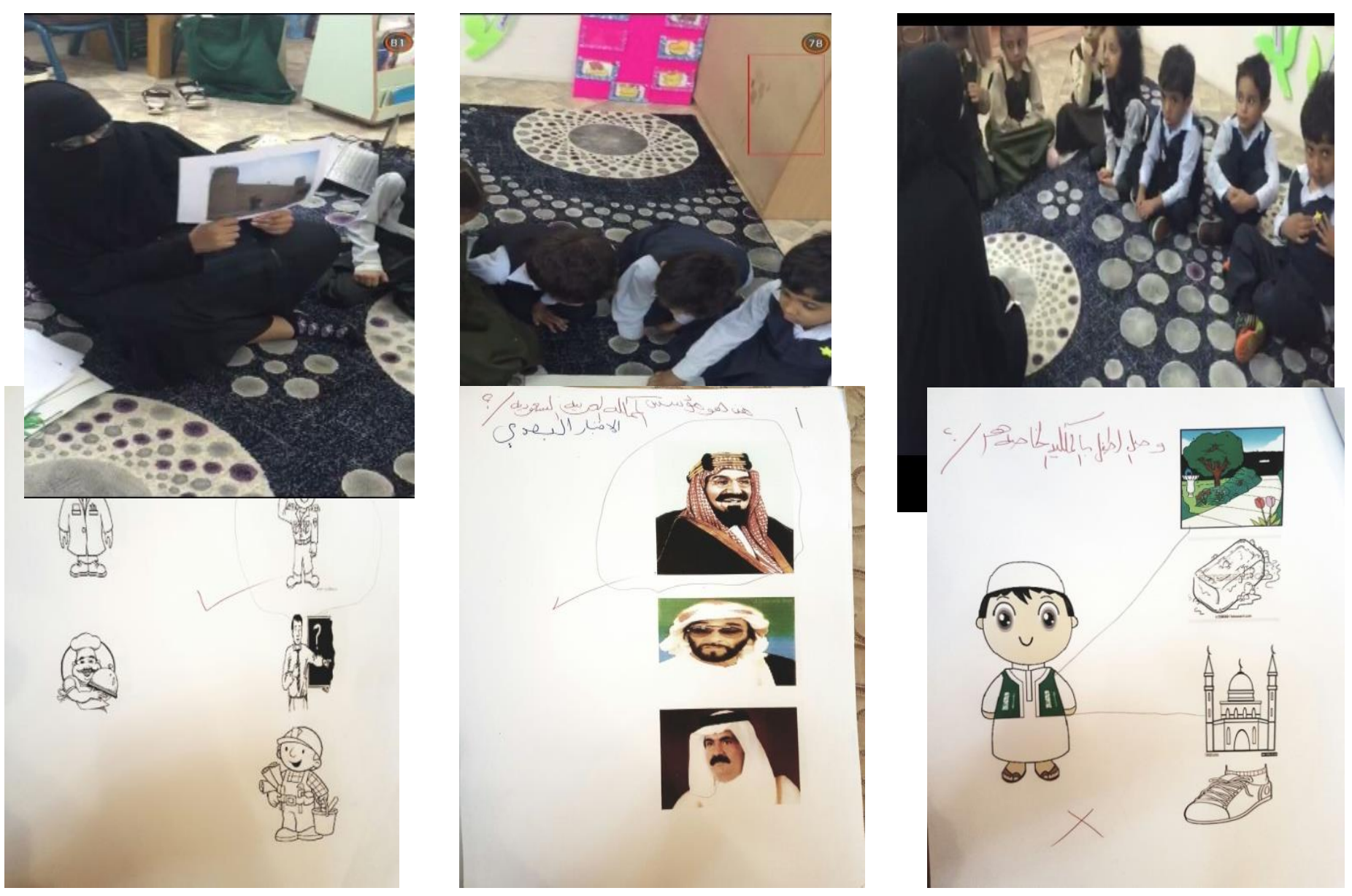